\title{
FACTORS AFFECTING THE PERFORMANCE OF TSHIOMBO IRRIGATION SCHEME IN LIMPOPO PROVINCE, SOUTH AFRICA
}

\author{
Liboster Mwadzingeni $^{1 \bowtie}$, Raymond Mugandani ${ }^{2}$, Paramu Mafongoya ${ }^{1}$
}

${ }^{1}$ University of KwaZulu-Natal, South Africa

${ }^{2}$ Midlands State University, Zimbabwe

\begin{abstract}
Smallholder irrigation farming is valuable for improving the welfare of rural communities in South Africa. Irrigation schemes in South Africa perform below average as some have collapsed. Boosting performance of irrigation schemes will ensure economic sustainability for low-income earners. There is little scholarly literature on factors affecting performance of smallholder irrigation schemes in South Africa. Therefore, this study assessed factors affecting yield and gross margin of sweet potato in the Tshiombo Irrigation Scheme. Data was collected using structured questionnaires, focus group discussions and in-depth interviews. The performance of the irrigation scheme was analysed using the ordinary least square method. The yield or gross margin of sweet potatoes were used as proxies for the scheme performance. Six estimators, namely age of farmers $(-0.022)$, labour availability $(-0.185)$, cultivated area $(-0.130)$, pesticide subsidy $(0.138)$, market price $(6.090)$, and distance of the plot from the main canal (0.191) significantly impacted performance of the scheme. A minimum participation of farmers in the value chain exposed them to lower market prices. The gross margin was generally low due to limited participation of aging farmers in the value chain. The performance of the scheme can be improved through providing and ensuring competitive prices and encouraging youth to participate in the scheme farming by providing lucrative market prices.
\end{abstract}

Keywords: Economic incentives, sustainability, gross margin, institutions, sweet potatoes

\section{INTRODUCTION}

Hunger and malnutrition are major challenges in the $21 \mathrm{st}$ century given that malnutrition has increased from 181.7 million in 1990-1992 to 232.5 million in 2014-2016 in Africa (Jha, 2019). In South Africa, high levels of malnutrition among resource-constrained smallholder farmers have propelled the government to adopt a National Development Plan (NDP) aimed at developing and improving the livelihoods of over 370,000 people mainly in rural areas (Pienaar and Traub, 2015). Agriculture is expected to eradicate hunger and improve nutritional security in the world by 2030 (FAO et al., 2018). Yet, persistent droughts due to dynamic climate events have reduced crop yields in rain-fed farming systems (Van Averbeke et al., 2011). On that account, the potential of smallholder irrigation schemes (SIS) in sustaining the livelihoods of 389 million people surviving on less than $\$ 1.90$ in sub-Saharan Africa (SSA) is widely acknowledged (Mundial, 2017). Smallholder irrigation schemes are of significant value in South Africa where $13.8 \%$ of the national households depend on subsistence agriculture as their key source of livelihood (Lehohla, 2016). SIS are useful in mitigating the negative effects of climate change such as water stress, mid-season and periodic dry spells, and crop failure (Mhembwe et al., 2019).

\footnotetext{
\Liboster Mwadzingeni, School of Agricultural, Earth and Environmental Sciences, P Bag X01, University of KwaZulu-Natal, Pietermaritzburg, South Africa, e-mail: libomwadzi@gmail.com, https://orcid.org/0000-0002-8015-7010
} 
Further, SIS in South Africa have the potential to significantly contribute to job creation, rural development and eradication of poverty (Cousins, 2013). The South African government has the potential to create 250,000 primary jobs and 130,000 secondary jobs mainly through expanding irrigated areas by $1.5-2$ million hectares (Cousins, 2015). Therefore, any untapped potential to enhance food security and employment through smallholder irrigation in South Africa needs to be explored.

In South Africa, SIS were developed to boost food production, secure agro-based livelihoods against prolonged dry spells and provide rural employment opportunities (Muchara et al., 2016; Fanadzo and Ncube, 2018). Farmers in SIS in South Africa collaborate to maintain the irrigation scheme infrastructure, irrigation scheduling and the marketing of produce (van Koppen et al., 2017). Unfortunately, many smallholder irrigation schemes in South Africa have collapsed while others are operating below optimum levels (van Koppen et al., 2017). Globally, factors such as water management, access to credit, access to market, poor maintenance, and age of scheme farmers have been found to be significant variables in determining the performance of SIS (Cousins, 2015; Valipour, 2015; Ward, 2016). Over one-third of the schemes in Limpopo Province are inactive, while $69 \%$ of large-scale centre-pivots are idle (van Koppen et al., 2017). Previous studies have concluded that the sustainability of smallholder irrigation in South Africa is constrained by market access, limited water allocation, land size, operational costs, production levels and institutional incompetence (Van Averbeke et al., 2011; Cousins, 2015; Mungai et al., 2016).

Crop yields and financial returns are the main standards of the irrigation scheme performance (Sinyolo and Mudhara, 2018). Consequently, farm income and cropping intensity are used to assess the performance of irrigation schemes in South Africa (Valipour, 2015). Improved performance of SIS can enhance social and economic status of rural communities (Fanadzo and Ncube, 2018). Problems of technical, financial and social feasibility have constantly arisen as decentralisation and farmer participation were incorporated into projects (Ward, 2016). These challenges were most likely to be perpetuated by the failure to implement monitoring and evaluation (M\&E) systems that are also required for farmers' enterprise management purposes (Ward, 2016).
In light of these challenges, this paper seeks to explore factors that affect scheme performance. The results of this study can be used to improve the sustainability of irrigation schemes.

\section{RESEARCH METHODS}

\section{Studied Area Description}

This study concerns the Tshiombo Irrigation Scheme (TIS) that is situated $40 \mathrm{~km}$ from Thohoyandou in Thulamela Municipality of Vhembe District in Limpopo Province of South Africa (Fig. 1). The province has 180 of 302 SIS in the country (van Koppen et al., 2017, Averbeke, 2012). The Tshiombo Irrigation Scheme is among the largest irrigation schemes in Limpopo Province, covering an area of 1,196 ha in the western end of Tshiombo valley (Lahiff, 1997). Sweet potato is the main crop grown in TIS because of its adaptability in many different areas, flexibility of planting and harvesting scheduling, drought tolerance and their contribution to household food security (Motsa et al., 2015).

\section{Data collection}

The study was conducted among households participating in TIS. Data and information were collected on demographic variables and current agronomic practices employed by farmers participating in TIS. The method of proportionate stratified random sampling was used to select 148 scheme farmers from the head, middle and tail section of irrigation scheme at $95 \%$ confidence level using Rao Soft statistical software (Raosoft, 2004). TIS was stratified into the head, middle and tail sections based on the number of farmers in each section. Gomo et al. (2014) use stratified random sampling to classify SIS into head, middle and tail sections. Fortynine scheme farmers were randomly selected and interviewed from each of the three sections of the irrigation scheme; the head, middle and tail. Questionnaires that were validated by a pilot test were administered by trained enumerators.

Face to face interviews were conducted using a structured questionnaire. Variables that were captured include household name, education level, size of land under irrigation as well as yield, sales price, inputs, area, and costs related to sweet potato production. In-depth interviews were done to collect information from extension workers, chiefs and committee members. 


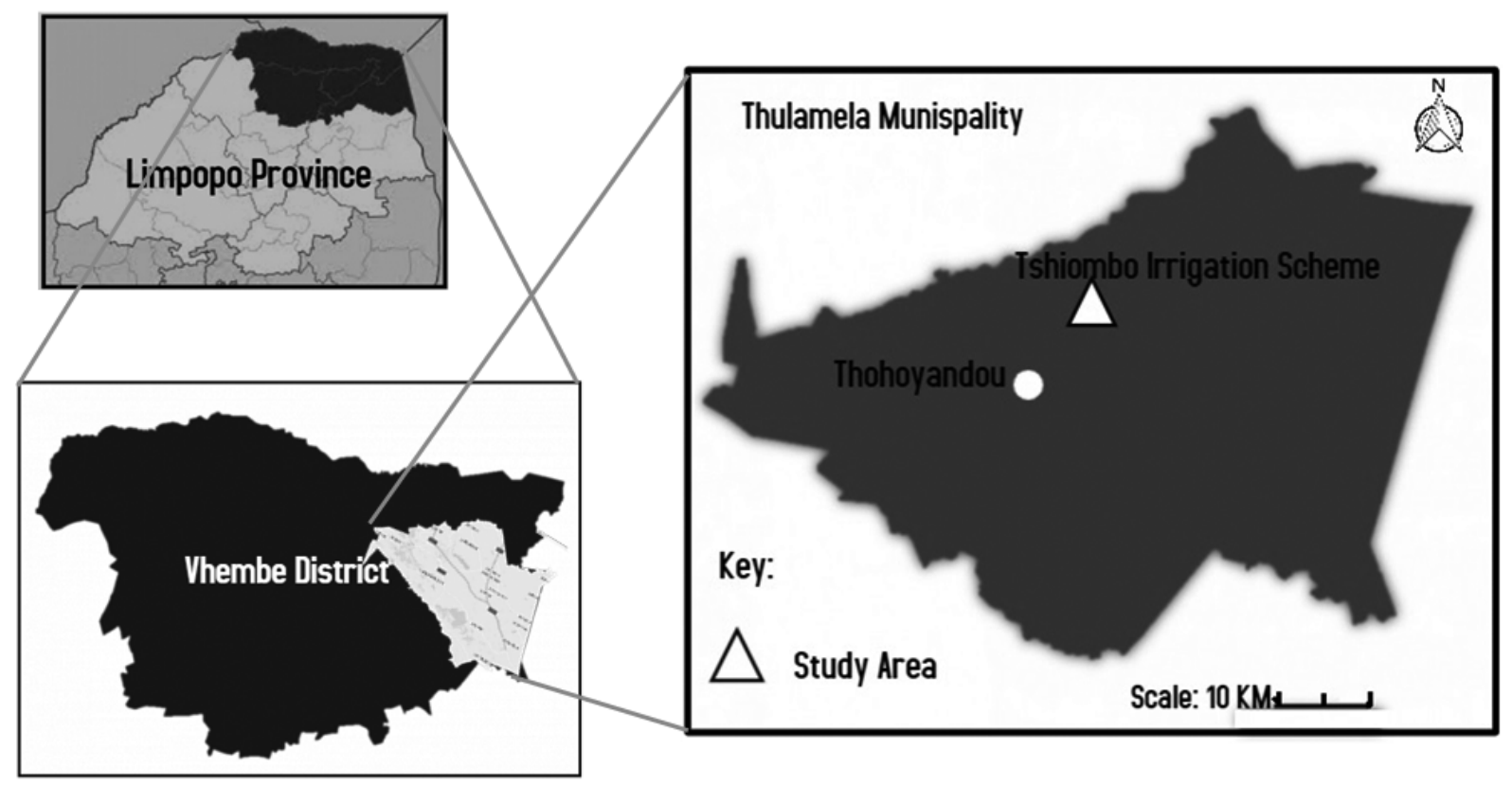

Fig. 1. Tshiombo Irrigation Scheme Source: own elaboration.

\section{Data Analysis}

Descriptive statistics, return on investment (ROI), gross margin (GM), and ordinary least square (OLS) regression were used for this study. A general-purpose statistical software package, STATA, was used to analyse data. The gross margin and yield analyses were used to assess the performance of the irrigation scheme as in Muchara et al. (2016) and Cousins (2013). Equations 1 and 2 show how gross margin $(\mathrm{GM})$ of sweet potato was calculated, while equations 3 and 4 show how gross income (GI) and total variable cost (TVC) were calculated.

The gross margin model is calculated as follows:

Gross Margin $(\mathrm{GM})=$ Gross Income $(\mathrm{GI})-$ Total Variable Cost (TVC)

where:

$$
\begin{aligned}
\mathrm{GM}= & \sum n i=1 P_{i} Q_{i}-\Sigma n i=1 P_{i} X_{i} \\
\mathrm{GI}= & \text { Quantity of Output (Qi) } \times \\
& \text { Price of Output (Pi) }
\end{aligned}
$$

$\mathrm{TVC}=\Sigma n i=1 P_{i} Q_{i}=$ Quantity of Intput (Qi) $\times$ Price of Intput $(\mathrm{Pi})$

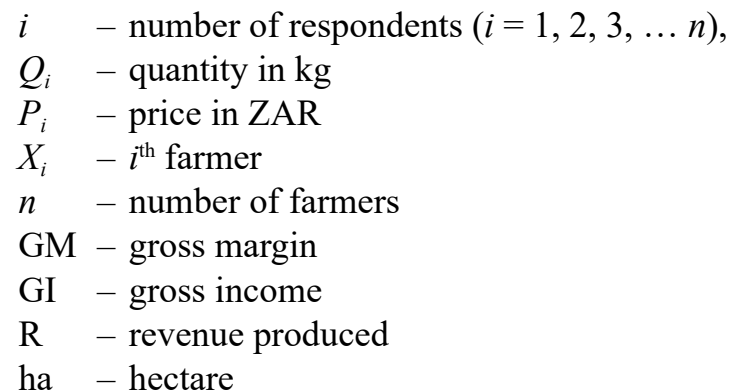

OLS with multiple explanatory variables which fall under multiple linear regression model was used for this study. OLS was determined as follows:

$$
Y=\alpha+\beta_{1} X_{1}+\beta_{2} X_{2}+\ldots+\beta_{k} X_{k}+\varepsilon
$$

where:

$Y$ - gross margin of sweet potato,

$\alpha$ - the value of $Y$ when all values of explanatory variables are zero

$\beta$ - the average change in $Y$ that is associated with a unit change in $X$

$X-$ is the explanatory variable

$\varepsilon-$ error term. 
Mwadzingeni, L., Mugandani, R., Mafongoya, P. (2020). Factors affecting the performance of Tshiombo Irrigation Scheme in Limpopo Province, South Africa. J. Agribus. Rural Dev., 3(57), 269-277. http://dx.doi.org/10.17306/J.JARD.2020.01314

The dependent variable, income from sweet potato was regressed against socio-economic explanatory variables collected in TIS. The sweet potato was the crop grown by the majority of the scheme farmers; therefore, its gross margin was more representative when compared to other crops. The key assumption of the study was that the gross margin of sweet potato is representative for all other performance indicators. A reweighted iterative regression procedure was used to produce a constant estimate of sweet potato gross income per year as transfer function models are not necessarily consistent (Muller and Wei, 1997). An iterative method is a regularly used technique to search in a stepwise fashion for the best value of estimates (Abdi, 2007).

The extent to which the variance of the coefficient estimate is being inflated by multicollinearity was estimated by means of a variance inflation factor (VIF), while the F-test was used to check if the model is better suited for analysing the data (Javed et al., 2016). The chi-square goodness of fit was used to find out how the observed value of the given phenomenon is significantly different from the expected value. It tells us if the sample data is representative of the actual population.

\section{RESULTS}

\section{Household Characteristics}

Table 1 below shows socio-demographic characteristics of farmers in TIS. Based on the questionnaire survey, results from the study show that $76.4 \%$ of respondents were female. Among the female respondents, 53.1\% were married. The majority of farmers in TIS were married given that approximately two-thirds of all respondents were married (Table 1). It was also observed that the scheme was dominated by ageing farmers (average of 59 years) as shown in Table 1. There was a significant difference in the marital status of male and female respondents $(\mathrm{P} \leq 0.01)$, as a considerably higher number of female farmers were not married compared to male farmers (Table 1). Data from the questionnaire survey reveal that approximately two-thirds of the respondents had access to extension services. Irrigation plots in TIS were owned for an average of 29 years. The average household size for the respondents was 6 members. Answers provided by the respondents participating in TIS show that sweet potato was the main crop grown by $89.2 \%$ of the scheme participants. The crop had a return on investment (ROI) of 1.28. Furthermore, findings
Table 1. Selected socio-demographic characteristics of the respondents

\begin{tabular}{|c|c|c|c|c|}
\hline Variable & Frequency & Percentage & Mean & $\begin{array}{l}\text { Standard } \\
\text { deviation }\end{array}$ \\
\hline \multicolumn{5}{|l|}{ Gender } \\
\hline Male & 35 & 23.65 & & \\
\hline Female & 113 & 76.35 & & \\
\hline \multicolumn{5}{|l|}{ Marital status } \\
\hline Married & 92 & 62.16 & & \\
\hline Unmarried & 56 & 37.84 & & \\
\hline \multicolumn{5}{|c|}{ Access to extension services } \\
\hline Yes & 100 & 67.57 & & \\
\hline No & 48 & 32.43 & & \\
\hline \multicolumn{5}{|l|}{ Access to credit } \\
\hline Yes & 11 & 7.43 & & \\
\hline No & 137 & 92.57 & & \\
\hline \multicolumn{5}{|l|}{ Main crop } \\
\hline Sweet potato & 132 & 89.19 & & \\
\hline Others & 16 & 10.81 & & \\
\hline \multicolumn{5}{|c|}{ Age of household head (years) } \\
\hline$\leq 30$ & 4 & 2.70 & \multirow{6}{*}{58.70} & \multirow{6}{*}{12.75} \\
\hline $31-40$ & 8 & 5.41 & & \\
\hline $41-50$ & 21 & 14.19 & & \\
\hline $51-60$ & 51 & 34.46 & & \\
\hline $61-70$ & 44 & 29.73 & & \\
\hline$\geq 71$ & 20 & 13.51 & & \\
\hline \multicolumn{5}{|c|}{ Household size (members) } \\
\hline $1-3$ & 17 & 11.49 & \multirow{4}{*}{6} & \multirow{4}{*}{3.00} \\
\hline $4-6$ & 73 & 49.32 & & \\
\hline $7-9$ & 41 & 27.70 & & \\
\hline$\geq 10$ & 17 & 11.49 & & \\
\hline \multicolumn{5}{|c|}{ Period of plot ownership (years) } \\
\hline $1-20$ & 56 & 37.84 & & \\
\hline $21-40$ & 55 & 37.16 & 29 & 15.08 \\
\hline$\geq 41$ & 37 & 25.00 & & \\
\hline $\begin{array}{l}\text { Area under sweet } \\
\text { potatoes (ha) }\end{array}$ & & & 0.40 & 0.20 \\
\hline $\mathrm{ROI}(Z A R)$ & & & 1.28 & 0.32 \\
\hline
\end{tabular}

Source: research survey, 2018. 
Mwadzingeni, L., Mugandani, R., Mafongoya, P. (2020). Factors affecting the performance of Tshiombo Irrigation Scheme in Limpopo Province, South Africa. J. Agribus. Rural Dev., 3(57), 269-277. http://dx.doi.org/10.17306/J.JARD.2020.01314

show that only $7.4 \%$ of all the respondents were able to access credit.

\section{The Yield of Sweet Potato}

Figure 2 shows the yield of sweet potato in TIS. An average yield of $2.4 \mathrm{t} / \mathrm{ha}$ of sweet potato was produced. The yield of sweet potato is clustered below average as shown in Figure 2 below. The yield of sweet potato is widely spread, given a standard deviation of $2.2 \mathrm{t} / \mathrm{ha}$. The majority of the respondents produced an average yield of 2.386 tonnes per hectare.

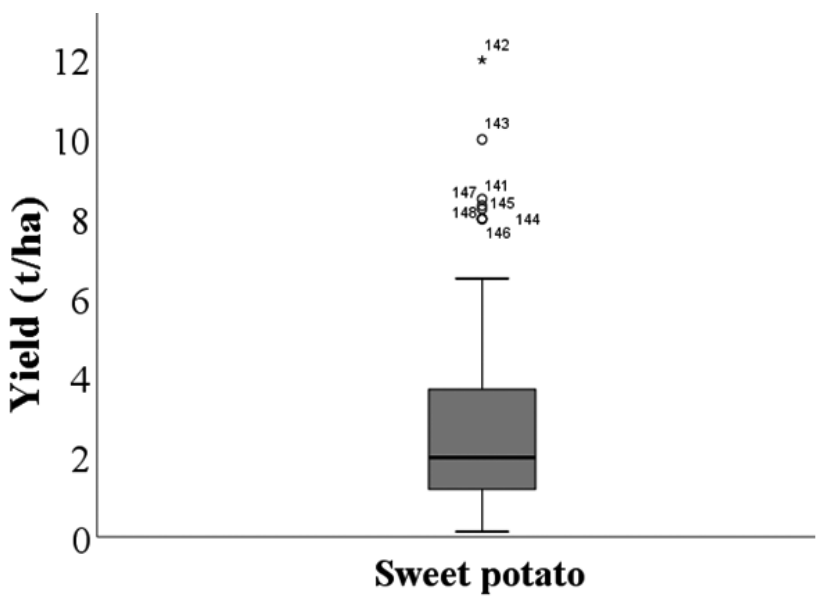

Fig. 2. Yield of Sweet potato per hectare Source: research survey, 2018.

\section{Gross margin of sweet potatoes}

Table 2 below shows that the respondents get an average gross margin (GM) of ZAR 29,169.61. On average, each respondent earns a gross income of ZAR 39,739.06 and total variable costs (TVC) of ZAR 17,463.11.

\section{Factors Affecting Gross Margin of Sweet Potatoes}

In this study, OLS was used to estimate factors affecting the gross margin of sweet potato as well as to explore the extent to which the gross margin was influenced by each factor. The Chi-square test indicates that OLS is statistically significant $(\mathrm{P}<0.01)$, therefore the model fits well for further analysis. Socio-economic factors significantly affect the gross margin of sweet potato.

Age of household head, labour per household, size of land cultivated, price, the distance of plot from the
Table 2. Gross margins analysis for sweet potato crops grown in the Tshiombo Irrigation Scheme

\begin{tabular}{lcc}
\hline \multicolumn{1}{c}{ Production cost item } & Amounts (ZAR) \\
\hline Gross income & & $\mathbf{3 9 , 7 3 9 . 0 6}$ \\
Transport cost & seed & 268.47 \\
Inputs: & fertiliser & $4,012.12$ \\
& pesticide & $4,533.55$ \\
& & 299.57 \\
Land preparation & planting & $3,165.10$ \\
Labour: & weeding & $1,305.44$ \\
& irrigating & $1,195.94$ \\
& spraying & $1,025.25$ \\
Harvesting & & 533.03 \\
Total variable costs & & $1,124.64$ \\
Gross margin & & $\mathbf{1 7 , 4 6 3 . 1 1}$ \\
\hline
\end{tabular}

Source: research survey, 2018.

main canal, and pesticide subsidy significantly influence the yield and gross margin of sweet potato (Table 3). The age of household head, labour force per household, size of cultivated land impacted the productivity of potatoes negatively, while pesticide subsidy, the market price of sweet potatoes and distance from the main canal to the plot had a positive impact on income received from sweet potatoes.

The age of household head, household size, and size of irrigation land cultivated contributed to the reduction of the yield of sweet potato as shown in Table 3. On the contrary, pesticide subsidy, market price and distance from the main canal positively influenced the yield of sweet potatoes (Table 3). An increase of age by a year statistically decreased the gross margin of sweet potatoes by $0.02 \%$ (Table 3 ). As the age of participants increases their gross margin decreases. An increase in household size significantly decreases the GM of sweet potato by a margin of $0.19 \%(\mathrm{P}<0.01)$. The increase in the cultivated area by a hectare results in a decrease of gross margin by a margin of 0.13 . Also, access to a unit of pesticide subsidies result in an increase of gross margin by a margin of 0.14 (Table 3). From the results, an increase in the market price of sweet potato by 1.00 
Table 3. OLS results on the factors which affect the gross margin of sweet potatoes

\begin{tabular}{lcc}
\hline \multicolumn{1}{c}{ Factor } & Coefficient & P-value \\
\hline Constant & $\mathbf{9 . 2 2 0}$ & $\mathbf{0 . 0 0 0}$ \\
Gender & $\mathbf{0 . 1 1 1}$ & $\mathbf{0 . 0 9 8}$ \\
Age & $\mathbf{- 0 . 0 2 2}$ & $\mathbf{0 . 0 0 9}$ \\
Formal education & -0.026 & 0.178 \\
Household size & $\mathbf{- 0 . 1 8 5}$ & $\mathbf{0 . 0 0 4}$ \\
Years in irrigation farming & 0.003 & 0.639 \\
Extension contact & 0.072 & 0.121 \\
Plot fee & 0.008 & 0.612 \\
Area cultivated & $\mathbf{- 0 . 1 3 0}$ & $\mathbf{0 . 1 8}$ \\
Fertiliser subsidy & 0.000 & 0.827 \\
Pesticide Subsidy & $\mathbf{0 . 1 3 8}$ & $\mathbf{0 . 0 0 1}$ \\
Subsidised land preparation & 0.064 & 0.666 \\
Social grants & 2.169 & 0.794 \\
Hawking & -2.756 & 0.365 \\
Market price & $\mathbf{6 . 0 9 0}$ & $\mathbf{0 . 0 4 1}$ \\
Distance from the main canal & $\mathbf{0 . 1 9 1}$ & $\mathbf{0 . 0 4 8}$ \\
State of irrigation infrastructure & -0.091 & 0.370 \\
Credit & 0.019 & 0.623 \\
Maintenance fee & 0.001 & 0.850 \\
Years in market participation & -0.003 & 0.576 \\
Total livestock units & 9.208 & 0.663 \\
\hline & & \\
\hline
\end{tabular}

Source: estimated from research survey, 2018.

ZAR leads to a 6.00 ZAR increase in sweet potato income. A unit increase in distance from the main canal to the plot leads to 0.19 units increase in sweet potatoes production.

\section{DISCUSSION}

Respondents participating in TIS have a household size of 6 members on average (Table 1). An increase in household size resulted in a significant reduction of GM (Table 1). The study noted that an increase in household size does not translate into an increase in labour availability in TIS. The majority of household members opt to engage in other economic activities which are more lucrative due to a lack of motivation for farming, leaving the household head responsible for all farming activities (Njoko and Mudhara, 2017). Hence, the majority of farmers opt to hire extra labour to work in the plots.

The results further reveal that respondents participating in the irrigation scheme own an average of 1.27 ha (Table 1). A study by Van Averbeke et al. (2011) revealed that farmers participating in irrigation schemes in South Africa own an average of 1.513 ha, hence, the size of plots in TIS is below the national average. An irrigated plot with an area above 0.5 ha is sufficient to meet food security needs at the household level (Van Averbeke et al., 2011)). Despite this, the majority of land was under-utilised preventing the households to meet their livelihood needs. Findings from the FGDs discussions and KIIs interviews support that the land was not utilised enough, hence food and income security for their livelihood was greatly compromised.

The average yield of sweet potato was $2.4 \mathrm{t} / \mathrm{ha}$ in TIS (Fig. 2). However, this is far below the reported mean yields of 3.9-9.5 $\mathrm{t} / \mathrm{ha}$ in communal gardens (Motsa et al., 2015). Given that the yield gap of sweet potatoes in TIS and the proposed yield range of poorly-equipped environment, this shows a performance gap which needs to be explored further and addressed to boost the yield. The study reveals that a unit increase in cultivated land resulted in a negative change in GM significantly at 5\% level (Table 3). While some farmers fail to manage their crop production effectively as the size of land increases given that sweet potato is labour-intensive farming (Motsa et al., 2015). However, the lack of appropriate technology and relevant information results in poor enterprise success.

The study shows that $76.4 \%$ of the respondents participating in the scheme were women. Findings from the study support observations at Mogalatsane and Setlaboswane irrigation schemes in Limpopo Province where female farmers own an average of $64 \%$ of irrigation plots (Mapedza et al., 2016). Considering the dominance of women in TIS, policies and resources need to be gender-responsive so that women participating in the irrigation schemes have a commercial outlook. A study conducted in Botswana concluded that commercially oriented women in agriculture help to improve food security (Fehr and Moseley, 2019). Results obtained from this research further revealed that $53.1 \%$ of the female household heads were married. Although there was a high number of married household heads $(62.2 \%)$, 
a vast majority of male household heads $(91.4 \%)$ were married, only $(53.1 \%)$ of their female counterparts were married. Marital status affects access to services and resources like extension and loan among most African households (Mdlozini, 2017). This suggests a low likelihood of access to services and resources by a considerable number of female-headed households in TIS, considering the gender disparity in access to resources.

The age of farmers was significantly negatively correlated with the gross margin of sweet potato (Table 3). The majority of farmers reached the average age of 59 years, hence they are not active economically due to the advanced age. As the farmers becomes older, GM decreases further. In addition to this, elderly people in TIS who reach the age of 60 and above gain access to income in the form of social grants, hence they enjoy minimum incentives to engage in irrigation farming. Ageing has a diminishing effect on the performance of irrigation schemes and food security (Dube, 2018). Ageing affects the technical efficiency of the agricultural systems as older farmers are unwilling to change their practices and slow to adopt new technologies (Senyolo et al., 2018). Although age comes with wisdom and experience, elderly farmers face difficulties in the adoption of efficient irrigation practices (Mango et al., 2018).

For this study, pesticide subsidies increase GM by a margin of 0.138 , significantly at $1 \%$ level (Table 3 ). Irrigation farming in TIS is partly subsidised by the government and private organisations. The government of South Africa has long been noted for its role in supporting smallholder irrigation farming among all rural communities, particularly through its revitalisation programmes (Cousins, 2015; Ncube, 2018; Fanadzo and Ncube, 2018). Findings from FDGs reveal that farmers access subsidies for various operations such as land preparation, seeds for selected crops, fertilisers, and pesticides from the government of South Africa. Based on findings from KIIs and FGDs, subsidies offered mainly concerned the support of crops like maize which the government consider a key for meeting its goal towards food security. Hence, crops of low economic importance to a specific group of people as in TIS are not looked into mainly due to a top-down approach. The in-depth interviews showed that farmers participating in TIS diverted pesticides which were subsidised for maize production towards sweet potato production. Input subsidies are associated with an increased efficiency among farmers (Michael et al., 2018). Considering the findings from TIS, different input subsidies impacted scheme performance differently. Therefore, there is a need for the government to offer some subsidies to allow greater flexibility and target resources to the farmers' needs.

The study reveals that changes in the price of sweet potato positively impact the GM of sweet potato. Markets for sweet potatoes in TIS are mainly informal, hence, market prices are highly volatile and difficult to predict and are also characterised by extremely low prices during harvest periods. Farmers participating in TIS produce sweet potato with limited compliance with the requirements of locally operating formal and informal markets due to poor information on its profitability and demand (Fanadzo and Dube, 2019). This perpetuates a poor bargaining position of farmers, making them more exposed to extremely low prices. Moreover, the lack of access to formal markets results in some conflicts among scheme farmers given that some farmers gazettes lower prices which are not competitive for others. Despite this, an increase in market prices stimulates an increase in the production of sweet potato as farmers will be attracted by a more lucrative price. Therefore, ensuring a higher market price is a sure way of encouraging farmers to grow sweet potatoes. Given this scenario, there is a need for the intervention by the government to ensure that farmers access a stable market for sweet potatoes. Providing formal markets will help to improve the scheme performance and eradicate marketrelated conflicts within the scheme.

Empirical findings from the study show that the distance of the plot from the main canal positively impacted sweet potato production. A unit increase in the distance from the main canal to the plot leads to a 0.191 percentage increase in sweet potatoes production at a $5 \%$ level of significance (Table 3). Farmers with plots closer to the main canal are likely to produce crops that demand more water, while those away from the irrigation plot produce drought-resistant crops like sweet potato. A study by Gomo et al. (2014) concerning SIS in South Africa reported that water productivity is higher as the distance from the main canal increase. The sweet potato is a drought-tolerant, short maturing crop (Low et al., 2020). Hence, the production of sweet potato in plots that are far away from the main irrigation canal is more viable as it has smaller water requirements compared to other crops grown in the scheme. Findings from the in-depth interviews indicated that as the distance from the main canal increased, water access subsequently decreased. 


\section{CONCLUSION}

SIS are a key resource among rural communities in South Africa in the face of climate change, therefore, a continuous assessment of their performance is important to identify spatial and temporal factors that need to be altered to ensure their sustainability. In TIS, there are various factors that affect the scheme performance. Also, the impact of ageing on the performance of SIS should not be underestimated as it limits farmers' participation in the value chain. Hence, the future of TIS is more likely to be characterised by poor performance and low sustainability due to the limited participation of young farmers. Integrating research and development will enable scheme farmers to acquire knowledge helping them to utilise their resources more efficiently and improve their productivity which may help them maximise their profit margins. The policy should focus on incorporating young farmers into irrigation farming to bridge the participation gap between aged farmers and young farmers. There is a need to shift support from input subsidies to cash disbursements to allow for greater autonomy in resource allocation. The farmer support systems should integrate scheme farmers into lucrative markets.

\section{SOURCE OF FUNDING}

South Africa's National Research Foundation (NRF) grant number 86893 .

\section{ACKNOWLEDGEMENT}

Extension workers taking part in the Tshiombo Irrigation Scheme for their assistance during data collection. Farmers taking part in the Tshiombo Irrigation Scheme for their consent to participate in this study. Thulamela Municipality Department of Agriculture, Forestry and Fisheries for the authorisation of this study and their support. And NRF for funding this study.

\section{REFERENCES}

Abdi, H. (2007). Bonferroni and Šidák corrections for multiple comparisons. Encyc. Meas. Stat., 3, 103-107.

Cousins, B. (2013). Smallholder irrigation schemes, agrarian reform and 'accumulation from above and from below'in South Africa. J Agrar. Chan. 13(1), 116-139. https://doi. org/10.1111/joac. 12000
Cousins, B. (2015). Through a glass darkly': Towards agrarian reform in South Africa. In: B. Cousins, C. Walker (eds.), Land Divided, Land Restored. Land Reform in South Africa for the 21st Century (pp. 250-269). Auckland Park: Jacana.

Dube, A.K., Ozkan, B., Ayele, A., Idahe, D., Aliye, A. (2018). Technical efficiency and profitability of potato production by smallholder farmers: The case of Dinsho District, Bale Zone of Ethiopia. J. Dev. Agric. Econ., 10(7), 225-235. https://doi.org/10.5897/jdae2017.0890

FAO, IFAD, UNICEF, WFP, WHO (2018). The State of Food Security and Nutrition in the World 2017. Building resilience for peace and food security. Rome: FAO Report.

Fanadzo, M., Dube, E. (2019). Best management practices boost yields in smallholder irrigation schemes. Water Wheel, 18(4), 30-34.

Fanadzo, M., Ncube, B. (2018). Challenges and opportunities for revitalising smallholder irrigation schemes in South Africa. Water SA, 44(3), 436-447. http://dx.doi. org/10.4314/wsa.v44i3.11

Fehr, R., Moseley, W.G. (2019). Gardening matters: a political ecology of female horticulturists, commercialization, water access, and food security in Botswana. Afr. Geo. Rev, 38(1), 67-80. https://doi.org/10.1080/19376812.2017.1286247

Gomo, T., Senzanje, A., Mudhara, M., Dhavu, K. (2014). Assessing the performance of smallholder irrigation and deriving best management practices in South Africa. Irr. Drain., 63(4), 419-429.

Javed, I., Ashfaq, M., Adil, S.A., Bakhsh, K. (2016). Analysis Of Agricultural Trade Between Pakistan And United Arab Emirates: An Application Of Gravity Model. J. Agric. Res., 54(4), 787-799.

Jha, R. (2019). Introduction: Hunger and Malnutrition as Major Challenges in the 21 st Century. World Scientific. https://doi.org/10.1142/9789813239913_0001

Lahiff, E. (1997). Land, Water and Local Governance in South Africa: A Case Study of the Mutale River Valley Paper No 7. Rural Resources Rural Livelihoods Working Paper Series. Retrieved from: http://ageconsearch.umn.edu/record/30571/files/rr970007.pdf

Low, J.W., Ortiz, R., Vandamme, E., Andrade, M., Biazin, B., Grüneberg, W.J. (2020). Nutrient-dense orange-fleshed sweetpotato: advances in drought-tolerance breeding and understanding of management practices for sustainable next-generation cropping systems in sub-Saharan Africa. Front. Sust. Food. Syst., 12 May. https://doi.org/10.3389/ fsufs. 2020.00050

Lehohla, P. (2016). Community Survey 2016, Agricultural Households. Statistics SouthAfrica. Retrieved May $8^{\text {th }} 2018$ from: http://www.statssa.gov.za/publications/03-01-05/ Presentation_CS2016_Agricultural_Households.pdf 
Mango, N., Makate, C., Tamene, L., Mponela, P., Ndengu, G. (2018). Adoption of Small-Scale Irrigation Farming as a Climate-Smart Agriculture Practice and Its Influence on Household Income in the Chinyanja Triangle, Southern Africa. MDPI. Land., 7(2), 49. https://doi.org/10.3390/ land7020049

Mapedza, E., Van Koppen, B., Sithole, P., Bourblanc, M. (2016). Joint venture schemes in Limpopo Province and their outcomes on smallholder farmers livelihoods. Phys. Chem. Earth, A/B/C, 92, 92-98. https://doi.org/10.1016/j. pce.2015.10.016

Mdlozini, M. (2017). Production constraints and choice of farming practices across selected smallholder farming systems in KwaZulu-Natal. Retrieved from: https://researchspace.ukzn.ac.za/xmlui/handle/10413/14930

Mhembwe, S., Chiunya, N., Dube, E. (2019). The contribution of small-scale rural irrigation schemes towards food security of smallholder farmers in Zimbabwe. Jàmbá: J. Disas. Risk. Stud., 1-11. DOI: 10.4102/jamba.v11i1.674

Michael, A., Tashikalma, A.K., Maurice, D.C. (2018). Agricultural Inputs Subsidy in Nigeria: An Overview of the Growth Enhancement Support Scheme (GESS). Acta Univ. Agric. Silv. Mende. Brun., 66(3), 781-789. https:// doi.org/10.11118/actaun201866030781

Motsa, N.M., Modi, A.T., Mabhaudhi, T. (2015). Sweet potato (Ipomoea batatas L.) as a drought tolerant and food security crop. SA J. Sci., 111(11-12), 1-8. http://dx.doi. org/10.17159/sajs.2015/20140252

Muchara, B., Ortmann, G., Mudhara, M., Wale, E. (2016). Irrigation water value for potato farmers in the Mooi River Irrigation Scheme of KwaZulu-Natal, South Africa: A residual value approach. Agric. Wat. Man., 164, 243-252. https://doi.org/10.1016/j.agwat.2015.10.022

Muller, D., Wei, W.W. (1997). Iterative least squares estimation and identification of the transfer function model. J. Tim. Ser. Anal., 18(6), 579-592. https://doi. org/10.1111/1467-9892.00069

Mungai, L.M., Snapp, S., Messina, J.P., Chikowo, R., Smith, A., Anders, E., Richardson, R.B., Li, G. (2016). Smallholder farms and the potential for sustainable intensification. Front. Plan. Sci., 7, 1720. https://doi.org/10.3389/ fpls.2016.01720

Mundial, B. (2017). Atlas of sustainable development goals 2017: From world development indicators. Washington,
DC: World Bank. Retrieved from: https://openknowledge. worldbank.org/handle/10986/26306

Ncube, B.L. (2018). Farming Styles, Livelihoods and Social Differentiation of Smallholder Farmers: Insights from New Forest Irrigation Scheme in Mpumalanga Province of South Africa. Retrieved from: http://hdl.handle. net/10566/4536

Njoko, S., Mudhara, M. (2017). Determinant of farmers' ability to pay for improved irrigation water supply in rural KwaZulu-Natal, South Africa. Water SA, 43(2), 229-237. http://dx.doi.org/10.4314/wsa.v43i2.07

Pienaar, L., Traub, L.N. (2015). Understanding the smallholder farmer in South Africa: Towards a sustainable livelihoods classification. AgEcon Search. Res. Agric. Appl. Econ. https://doi.org/10.22004/ag.econ.212633

Raosoft, I. (2004). Sample size calculator. Retrieved from: http://www.raosoft.com/samplesize.html

Senyolo, M.P., Long, T.B., Blok, V., Omta, O. (2018). How the characteristics of innovations impact their adoption: An exploration of climate-smart agricultural innovations in South Africa. J. Clean. Prod., 172, 3825-3840. https:// doi.org/10.1016/j.jclepro.2017.06.019

Sinyolo, S., Mudhara, M. (2018). The impact of entrepreneurial competencies on household food security among smallholder farmers in KwaZulu Natal, South Africa. Eco. Food Nutr., 57(2), 71293. https://doi.org/10.1080/036702 44.2017.1416361

Valipour, M. (2015). Land use policy and agricultural water management of the previous half of century in Africa. Appl. Wat. Sci., 5(4), 367-395. https://doi.org/10.1007/ s13201-014-0199-1

Van Averbeke, W., Denison, J., Mnkeni, P. (2011). Smallholder irrigation schemes in South Africa: A review of knowledge generated by the Water Research Commission. Water SA, 37(5), 797-808. http://dx.doi.org/10.4314/wsa. v37i5.17

van Koppen, B., Nhamo, L., Cai, X., Gabriel, M.J., Sekgala, M., Shikwambana, S., Tshikolomo, K., Nevhutanda, S., Matlala, B., Manyama, D. (2017). Smallholder irrigation schemes in the Limpopo Province, South Africa. Pretoria, South Africa: IWMI.

Ward, C. (2016). Improved Agricultural Water Management For Africa's Drylands. New York: World Bank Publications. https://doi.org/10.1596/978-1-4648-0832-6 